\title{
GC-MS Analysis of the Essential Oil and Methanol Extract of the Seeds of Steganotaenia araliacea Hochst
}

\author{
Mussie Sium Demoz ${ }^{*}$, Kareru Patrick Gachoki' ${ }^{1}$, Keriko Joseph Mungai1, \\ Berhane Girmay Negusse ${ }^{2}$ \\ ${ }^{1}$ Department of Chemistry, Jomo Kenyatta University of Agriculture and Technology, Nairobi, Kenya \\ ${ }^{2}$ Department of Chemistry, College of Health Sciences, Asmara, Eritrea \\ Email: ${ }^{*}$ mussies2002@yahoo.com, ${ }^{*}$ mussies2013@gmail.com
}

Received 9 October 2014; revised 16 November 2014; accepted 29 November 2014

Copyright $(02014$ by authors and Scientific Research Publishing Inc.

This work is licensed under the Creative Commons Attribution International License (CC BY). http://creativecommons.org/licenses/by/4.0/

(c) (i) Open Access

\begin{abstract}
Background: Steganotaenia araliacea is a multipurpose plant and has wider applications in the folklore for the treatment of various ailments. Previously the presence of antileukemic lignan lactones and saponins was detected in the stem bark, root and leaf of Steganotaenia araliacea. Besides, the diuretic and antibacterial activities of the plant were reported. However, there has been no attempt to examine the constituents of the seeds of Steganotaenia araliacea. This paper reports the first such study of both the essential oil and methanol extract of the seeds of the plant. Methods: The seeds of the plant were shade dried, pounded and thus extracted using methanol. Besides, the essential oil of the seeds was collected using steam distillation. The components of the methanol extract were studied both by GC-MS and preliminary phytochemical studies; the essential oil was running on GC-MS for analysis. Results: The GC-MS analysis of the essential oil of the seeds identified the presence of $\alpha$-linalool, $\alpha$-pinene, m-cresol, $p$-menth-1-en-4-ol, $p$-menth-1-en-8-ol, myristicin and others. Besides, the methanol extract of the seeds showed the presence of falcarinol, apiol, scoparone, stigmasterol, myristicin etc. The preliminary phytochemical analysis of the methanol extract of the seeds confirms the presence of alkaloids, flavonoids, tannins, coumarines, steroids, and phenols. Conclusion: This plant contains bioactive metabolites and thus can be used as an alternative and complementary medicine in treatment of different ailments. However, further studies on the bioactivity and toxicity of the plant should be done.
\end{abstract}

\section{Keywords}

GC-MS, Steganotaenia araliacea, Essential Oil, Phytochemicals

\footnotetext{
${ }^{*}$ Corresponding author.
}

How to cite this paper: Demoz, M.S., Gachoki, K.P., Mungai, K.J. and Negusse, B.G. (2014) GC-MS Analysis of the Essential Oil and Methanol Extract of the Seeds of Steganotaenia araliacea Hochst. American Journal of Plant Sciences, 5, 3752-3760. http://dx.doi.org/10.4236/ajps.2014.526392 


\section{Introduction}

Steganotaenia araliacea is a small tree up to $10 \mathrm{~m}$ tall, with leaves, which when crushed smell like carrots. It is exceptionally drought resistant but tolerates high rainfall. It occurs over a wide range of altitude. The plant is relatively widespread in Tropical Africa and is found in Mali, Cameroon and other regions of West Africa; Ethiopia, Somalia and Eritrea in East Africa and in a variety of locations in Southern Africa [1]. In Eritrea it is found both in open woodland and on riverbanks (1300 - $2100 \mathrm{~m})$. Given the wide distribution it is unsurprising that in different areas it has been used in a number of ways in traditional medicine [2]. In Eritrea it is used in treatment of arthritis, chronic ulcer, snakebite, gynecological problem, hypoglycaemia, sore-throat, diuretic, dysentery, hypotensive and wound healing [3]. Elsewhere in Africa Steganotaenia araliacea has been used against malaria and other opportunistic infections resulting from AIDS [4].

The analyses of the constituents of Steganotaenia araliacea were dominated by the observations concerning the occurrence of cytotoxic lignans, particularly in the stem-bark, leaf and roots. In 1973 Kupchan et al. reported the presence of antileukemic lignan lactones in Steganotaenia araliacea of Ethiopian origin [5]. Over the next 20 years there was extensive activity to investigate the structure of related lignans and saponins, mostly in those from Steganotaenia araliacea of West African origin [6]-[15]. In addition, these structural studies stimulated a flurry of synthetic chemistry [16]-[19]. Steganotaenia araliacea has been reported as a multipurpose plant and has wider applications in the traditional medical practices and thus certain researches are reported. A review of the studies related to the medicinal uses of the plant include: the antioxidant and antibacterial activities [20] [21], diuretic activity of the stem bark [22], antimitotic and antitubulin activity of stegancin found in that plant [23]. Moreover, the insecticidal application of the plant, as antiplasmodial [24], larvicidal activity of the leaves [25] and anti-leishmanial activity was also published [26]. The different parts of the plant especially the stem bark have been studied; however the bioactivity and chemical constituents of the seeds of the plant were not reported. In this paper we report the first such study of the methanol extracts and essential oil of the seeds of the plant.

\section{Materials and Methods}

\subsection{Plant Materials}

The seeds of Steganotaenia araliacea were collected from Bet-Gerghish near Asmara Zoo, Eritrea. The collection and identification of the plant was conducted with the help of a Taxonomist, Prof. Ghebrehiwet Asghedom of Eritrea Institute of Technology (EIT). Voucher specimen of the plant was prepared and deposited in the herbarium of EIT. The seeds were thoroughly rinsed twice in running tap-water and then in sterile water before being shade dried for 3 weeks. The seeds were then powdered using an electrical blender and kept in clean vials until extraction.

\subsection{Extraction}

The powdered seeds (25 g) of Steganotaenia araliaceae were placed in a thimble and extracted successively with methanol $(250 \mathrm{~mL})$ using Soxhlet extractor for $8 \mathrm{~h}$. The solvent extracts were concentrated under reduced pressure and afforded a crude extract (5.6 g, 22.4\%) which was preserved at $4{ }^{\circ} \mathrm{C}$ in airtight bottle container until further use. Steam distillation of the fresh seeds of Steganotaenia araliacea over 4 hours gave a distillate of water and a separate layer of the essential oil. The oil was separated by extracting the mixture using ether solvent and afforded $0.05 \% \mathrm{v} / \mathrm{w}$. The oil droplets, placed in closed vial, were preserved at low temperature for GC-MS analysis.

\subsection{Preliminary Phytochemical Analysis}

The methanol extract of the seed of Steganotaenia araliacea was screened using chemical tests for the presence of bioactive metabolites like alkaloids, saponins, phenols, steroids, flavonoids, carotenoids, and coumarines using standard protocols [27] [28].

\subsection{GC-MS Analysis}

The essential oil and the crude methanol extracts of the seeds were analysed in Southampton, England on a capillary GC column and the results were presented with 5\%, $1 \%$ and $0.2 \%$ cut offs of peak heights. The samples 
were run in duplicates and the raw data were studied and model interpretive results of the different chromatogram peaks were attempted from the GC-MS program. The identification of the compounds was made by observing their mass spectra and retention indices with the NIST library of 249,000 compounds using a search engine.

\subsection{The GC-MS Conditions}

The crude methanol extract and the essential oil of the seeds of Steganotaenia araliaceae were analyzed by GC/MS using a Thermofinnigan Trace GC/MS single quadrupole mass spectrometer with AS 800 autosampler The separations were achieved by capillary column, Phenomenex ZB5 $(30 \mathrm{~m} \times 0.25 \mathrm{~mm}$, film thickness 0.25 $\mu \mathrm{m})$. The column temperature was kept at $40^{\circ} \mathrm{C}$ for $4 \mathrm{~min}$ and then at different temperatures $\left(160^{\circ} \mathrm{C}, 220^{\circ} \mathrm{C}\right)$ at variable rates (10 deg/min, $2 \mathrm{deg} / \mathrm{min}$ ) for $10 \mathrm{~min}$. The flow rate of helium as carrier gas was $1 \mathrm{~mL} / \mathrm{min}$. MS was taken at $70 \mathrm{eV}$ electron ionisation, trap current $150 \mu \mathrm{A}$, source temperature $200^{\circ} \mathrm{C}$.

\section{Results}

In this study, the methanol extract and hydro-distillated essential oil of the seeds of the plant were analyzed. During the GC-MS analyses, the excellent separations achieved by the GC (Figure 1) permitted the inspection of each of the peaks and the comparison of the observed spectra for each constituent with those spectra of the NIST library. The results of the GC-MS analysis of the essential oil and the preliminary phytochemical analysis are shown in Table 1 and Table 2.

\section{Discussion}

Previously the essential oil composition from the leaflets of Steganotaenia araliaceae, from Cameroon, was analyzed and contains compounds like limonene, $\beta$-phellandrene, $\alpha$-pinene, sabinene, $\beta$-caryophyllene and crypton [29]. In the present study, as indicated in Table 1, the GC-MS analysis of the essential oil of the seeds identified the presence of $\alpha$-linalool, $\alpha$-pinene, m-cresol, $p$-menth-1-en-4-ol, $p$-menth-1-en-8-ol, myristicin as the major constituents. Essential oils work at the cellular level and most have antibacterial, antifungal, insecticidal and other biological effects. Besides, there are certain essential oils that actually lower insulin needs for diabetics and reduces blood sugar fluctuations [30]. The GC-MS analysis of the methanol extract of the seeds showed the presence of falcarinol, apiol, scoparone, stigmasterol, myristicin, 1-dodecosanol, nonacosanol, 9-

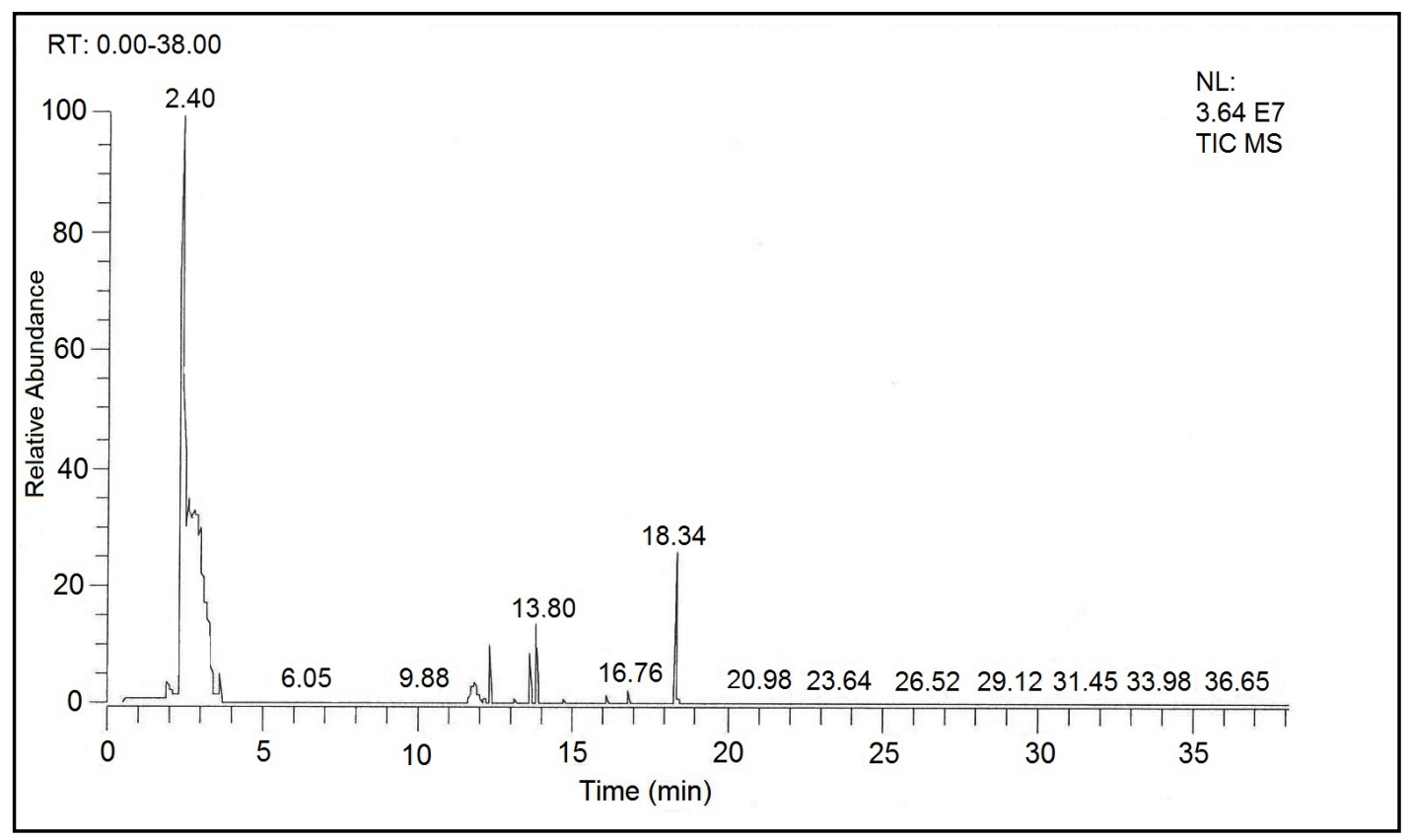

Figure 1. GC chromatogram of the essential oil of the seeds of Steganotaenia araliacea. 
Table 1. The major constituents of the essential oil of the seeds of Steganotaenia araliaceae.

\begin{tabular}{|c|c|c|c|}
\hline Compound & RT & $\%$ & SI \\
\hline$\alpha$-Pinene & 8.69 & 27.25 & 935 \\
\hline m-Cresol & 11.80 & 21.33 & 923 \\
\hline$\alpha$-Linalool & 12.29 & 14.15 & 919 \\
\hline p-Menth-1-en-4-ol & 13.61 & 10.48 & 930 \\
\hline p-Menth-1-en-8-ol & 13.80 & 18.72 & 948 \\
\hline$p$-Menth-1-en-8-ol, acetate & 16.06 & 1.94 & 920 \\
\hline 4-Allyl-1,2-dimethoxy-benzene & 16.76 & 2.38 & 911 \\
\hline Myristicin & 18.34 & 30.13 & 934 \\
\hline
\end{tabular}

Table 2. Phytochemical studies of the methanol extract of the seeds of Steganotaenia araliaceae.

\begin{tabular}{|c|c|c|}
\hline Phytochemical & Type of test & Inference/Result \\
\hline Alkaloids & Dragendroff's test/Mayer's test & + \\
\hline Flavonoids & Shinoda test/Lead acetate tests & + \\
\hline Tannins & Gelatin test/Ferric chloride test & + \\
\hline Steroids & Salkowski tests/Lieberman Burchardt tests & + \\
\hline Saponins & Foam test/Froth test & + \\
\hline Phenols & $\mathrm{FeCl}_{3}$ test/Liebermann's test & + \\
\hline Cardenolides & Keller Kiliani’s test & + \\
\hline Coumarines & Alcoholic sodium hydroxide & + \\
\hline Anthraquinone & Borntragers test & - \\
\hline
\end{tabular}

Note: $(+)=$ positive result; $(-)=$ negative result.

hexacosene etc. The mass spectra of four common bioactive molecules found in the methanol extract are shown in Figure 2. These results justify the following comments: 1) Apiol occurs in other members of the Apiaceaefamily and has had a significant role in the termination of pregnancy by provoking abortions [31]. 2) Scoparone (6, 7-dimethoxycoumarin) is recognised as a vasodilator, smooth muscle relaxant and ananti-inflammatory agent. It is an anti-asthmatic and has anti-hypertensive activity [32]. 3) Falcarinol, theanti-cancer compound found in carrots appears omnipresent in Steganotaenia araliaceae [33] [34]. 4) Stigmasterol is used in food supplements and is associated with a lowering of the risk of cancer [35]. The GC-MS results establish a number of candidates and show that the seeds of Steganotaenia araliaceae are rich in bioactive compounds. As shown on Table 2, the preliminary phytochemical analysis of the methanol extract of the seeds confirms the presence of alkaloids, flavonoids, carotenoids, coumarines, steroids, and phenols.

This plant has been recommended for different ailments including diabetes and hypertension by different herbalists. The preliminary results obtained confirm our starting hypothesis that aside from the well-established anti-cancer activity of the lignans from the roots of Steganotaenia araliaceae, this plant has other bioactive constituents, which on the one hand justify the interest in the plant of traditional healers and on the other merit a more detailed investigation of the seeds in order to elucidate the structure of the different compounds responsible 


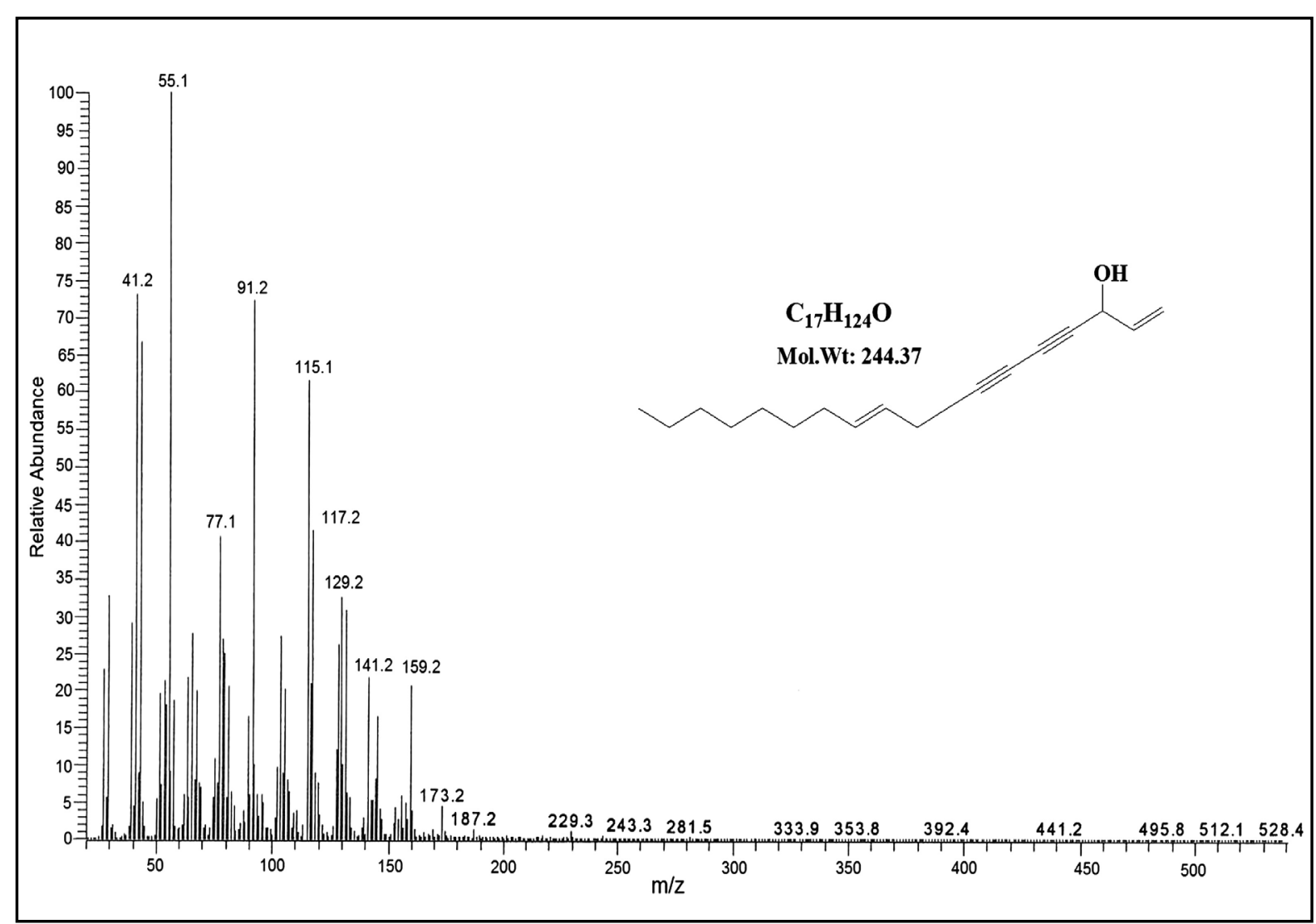

Mass spectrum of Falcarinol

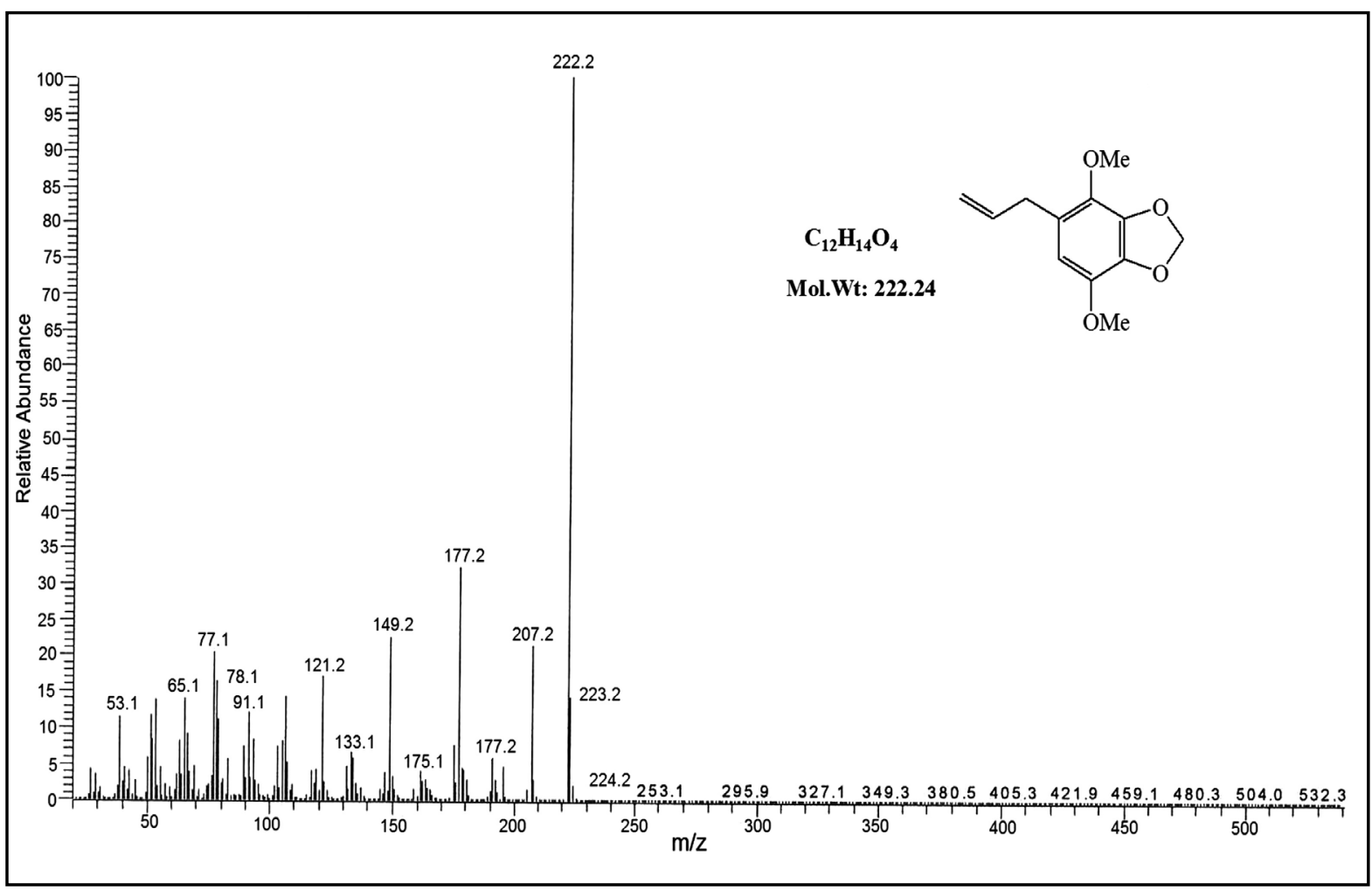

Mass spectrum of Apiol 


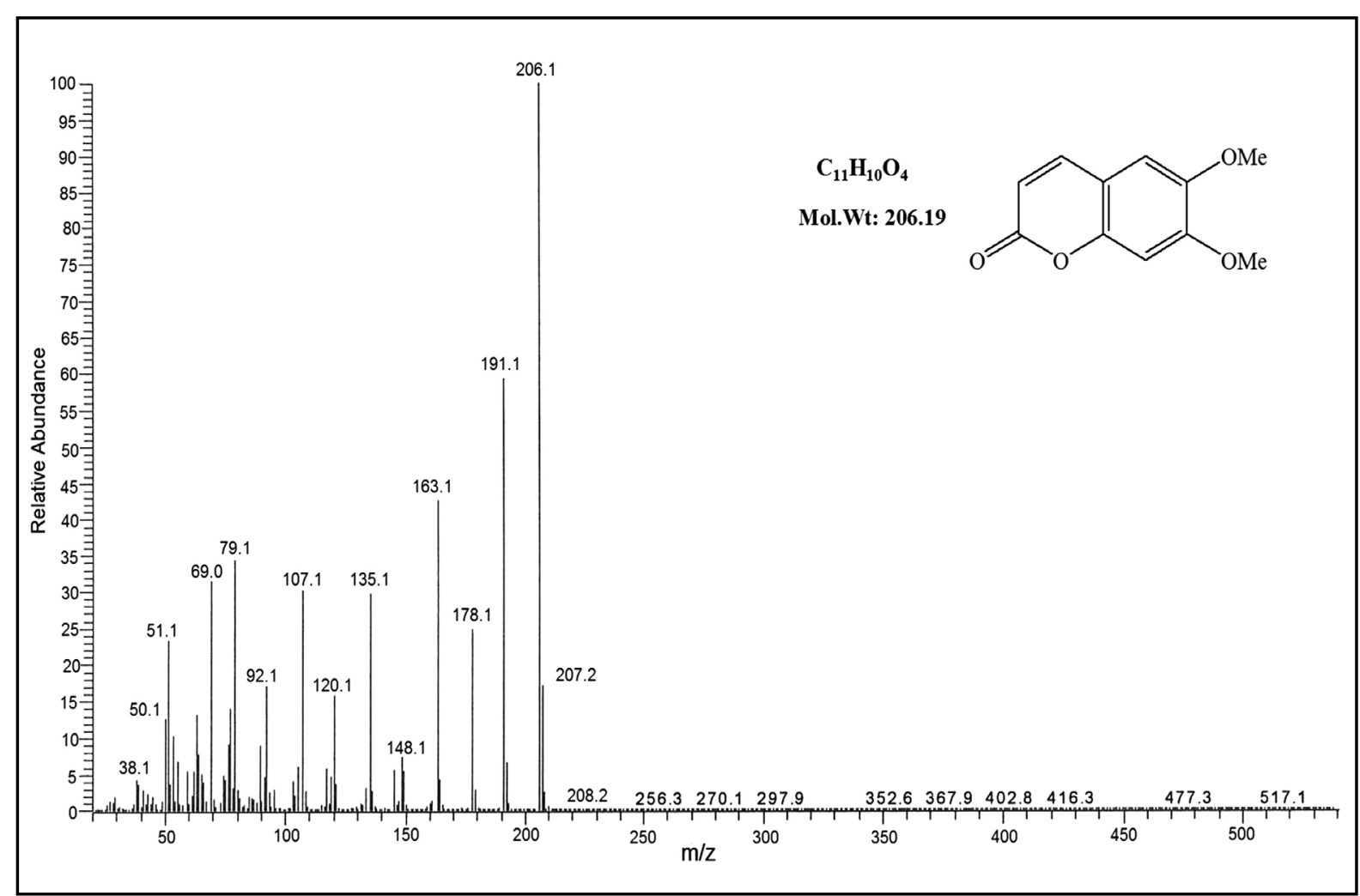

Mass spectrum of Scoparone

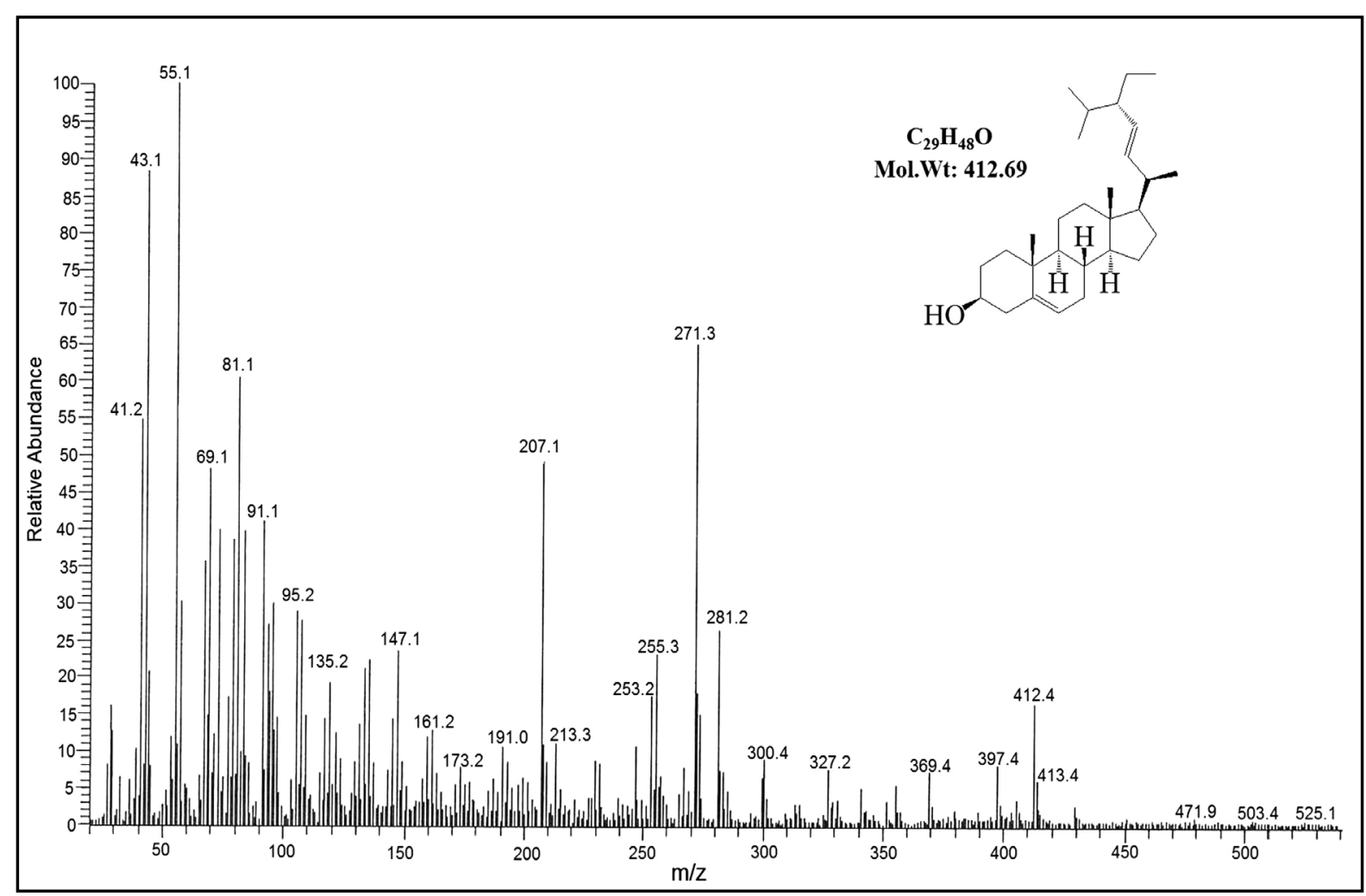

Mass spectrum of Stigmasterol

Figure 2. Mass spectra of the main bioactive molecules found in the methanol extract of the plant. 
for the observed activities. Based on the GC-MS analyses, some of the structures of the compounds present both in the essential oil and methanol extract of the seeds of the plant include:

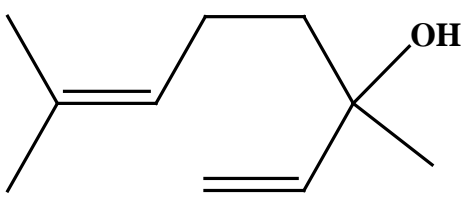

alpha-limonene

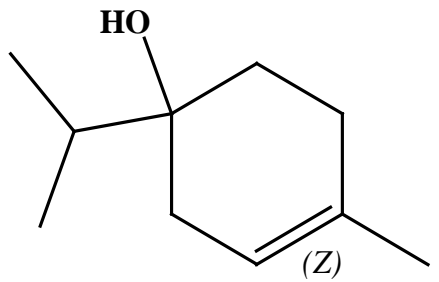

p-menth-1-en-4-ol

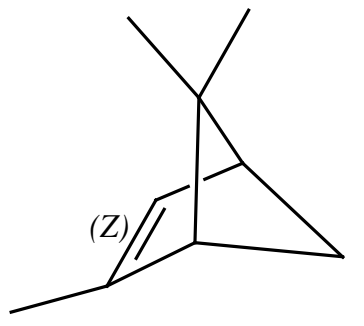

alpha-pinene

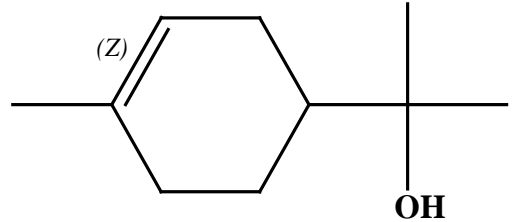

p-menth-1-en-8-ol

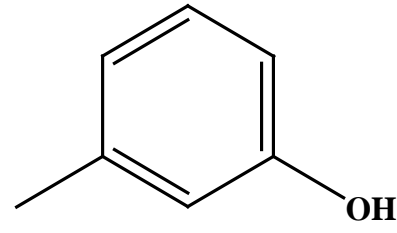

m-cresol

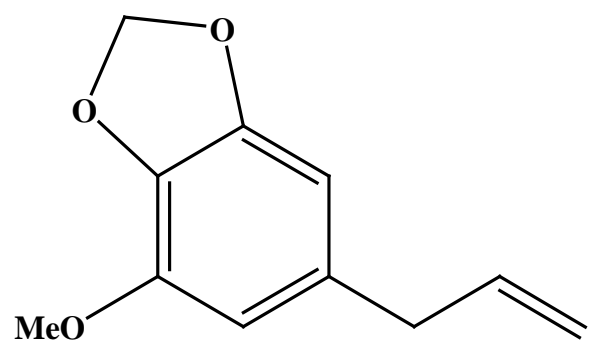

myristicin<smiles>C=CC(O)C#CC#CCC/C=C/CCCCCCCCCCCCCCCCCCC(C)(C)C(C)(C)C</smiles><smiles>C=CCc1cc(OC)c2c(c1OC)OCO2</smiles>

Stigmasterol<smiles>COc1cc2ccc(=O)oc2cc1OC</smiles>

\section{Apiol (5-Allyl-4,7-dimethoxy-benzo[1,3]dioxole)}

Scoparone (6,7-dimethoxycoumarine)

\section{Conclusion}

Steganotaenia araliaceae is traditionally used for the treatment of various ailments and its wider application can easily be noticed by the presence of the different bioactive molecules. Further studies on the efficacy and toxicity of the plant would be required to ensure its use for different ailments. 


\section{Acknowledgements}

The Authors greatly acknowledge the help of Prof Ghebrehiwet Medhanie, botanist in the Institute of Technology Eritrea for his help in plant collection. Thanks are due to the Mass Spectrometric group in the University of Southampton, UK for their GC-MS analyses.

\section{References}

[1] Mabberley, D.J. (1997) The Plant-Book. 2nd Edition, Cambridge University Press, Cambridge, 680.

[2] Bein, E., Habte, B., Jaber, A., Ann, B. and Tengnas, B. (1996) Useful Trees and Shrubs in Eritrea. Identification, Propagation and Management for Agricultural and Pastoral Communities. Regal Press Limited, Nairobi, 364.

[3] Senai, W.A. (2010) Legislative Regulation of Traditional Medicinal Knowledge in Eritrea vis-à-vis Eritrea's Commitments under the Convention on Biological Diversity: Issues and Alternatives. Law, Environment and Development Journal, 6/2, 130.

[4] Addy, M.E. (2005) Western Africa Network of Natural Products Research Scientific Meeting. African Journal of Traditional, Complementary and Alternative Medicine, 2, 177-205.

[5] Kupchan, S.M., Britton, R.W., Ziegler, M.F., Gilmore, C.J., Restivo, R.J. and Bryan, R.F. (1973) Tumor Inhibitors. Steganacin and Steganangin, Novel Antileukemic Lignan Lactones from Steganotaenia araliacea. Journal of American Chemical Society, 95, 1335-1336. http://dx.doi.org/10.1021/ja00785a054

[6] Taafrout, M., Rouessac, F. and Robin, J.-P. (1983) Araliangine, a New Bisbenzocyclo-Octadienolactonic Lignan from Steganotaenia araliacea, Hochst. Tetrahedron Letter, 24, 197-200. http://dx.doi.org/10.1016/S0040-4039(00)81364-7

[7] Taafrout, M., Rouessac, F. and Robin, J.-P. (1983) Neoisostegane, a New Bisbenzocyclo-Octadienolactonic Lignan from Steganotaenia araliacea, Hochst. Tetrahedron Letter, 24. 2983-2986. http://dx.doi.org/10.1016/S0040-4039(00)88075-2

[8] Taafrout, M., Rouessac, F. and Robin, J.-P. (1983) Prestegane A. from Steganotaenia araliacea Hochst.: The First Natural Dibenzylbutanolide Lignan with a Meta-Phenol—A Short Synthesis of Cis- and Trans-( \pm )-Arctigenin. Tetrahedron Letter, 24, 3237-3238. http://dx.doi.org/10.1016/S0040-4039(00)88144-7

[9] Hicks, R.P. and Sneden, A.T. (1983) Neoisostegane, a New Bis-Benzocyclooctadiene Lignan Lactone from Steganotaenia araliacea Hochst. Tetrahedron Letter, 24, 2987-2990.

[10] Taafrout, M., Rouessac, F., Robin, J.-P., Hicks, R.P., Slillady, D.D. and Sneden, A.T. (1984) Neoisostegane, a New Bisbenzocyclooctadiene Lignan Lactone from Steganotaenia araliacea. Journal of Natural Products, 47, 600-606. http://dx.doi.org/10.1021/np50034a005

[11] Robin, J.P., Davoust, D. and Taafrout, M. (1986) Steganolides B and C, New Lignans Analogous to Episteganacin and Isolated from Steganotaenia araliacea Hochst. Carbon-13-Proton Correlation of Staganacin Using Two-Dimensional NMR. Tetrahedron Letters, 27, 2871-2874. http://dx.doi.org/10.1016/S0040-4039(00)84666-3

[12] Kapundu, M., Kakera, L.K., Graftieaux, A. and Delaude, C. (1987) Chemical Study of the Saponin from Steganotaenia araliacea Hoechst. Bulletin of Society Royal Science Liege, 56, 125-128.

[13] Lavaud, C., Massiot, G., Le Men-Olivier, L., Viari, A., Vigny, P. and Delaude, C. (1992) Saponins from Steganotaenia araliacea. Phytochemistry, 31, 3177-3181. http://dx.doi.org/10.1016/0031-9422(92)83470-J

[14] Wickramaratne, D.B.M., Pengsuparp, T., Mar, W., Chai, H.B., Chagwedera, T.E., Beecher, C.W.W., Farnsworth, N.R., Kinghorn, A.D., Pezzuto, J.M. and Cordell, G.A. (1993) Novel Antimitotic Dibenzocyclo-Octadiene Lignan Constituents of the Stem Bark of Steganotaenia araliacea. Journal of Natural Products, 56, 2083-2090. http://dx.doi.org/10.1021/np50102a009

[15] Meragelman, K.M., McKee, T.C. and Boyd, M.R. (2001) 10-Demethoxystegane, a New Lignan from Steganotaenia araliacea. Journal of Natural Products, 64, 1480-1482. http://dx.doi.org/10.1021/np010248h

[16] Hughes, L.R. and Raphael, R.A. (1976) Synthesis of the Antileukemic Lignan Precursor ( \pm ) Steganone. Tetrahedron Letters, 17, 1543-1546. http://dx.doi.org/10.1016/S0040-4039(00)71306-2

[17] Robin, J.P., Gringore, O. and Brown, E. (1980) Asymmetric Total Synthesis of the Antileukemic Lignan Precursor (-)Steganone and Revision of Its Absolute Configuration. Tetrahedron Letters, 21, 2709-2712. http://dx.doi.org/10.1016/S0040-4039(00)78586-8

[18] Taafrout, M., Rouessac, F., Robin, J.P. and Davoust, D. (1984) Isolation of Prestegane B, the First Bis-(m-hydroxydenzyl)butanelide Lignan of Plant Origin, from Steganotaenia araliacea Hochst. Isolation and One-Step Synthesis of Dimethyl Matairesinol. Tetrahedron Letters, 25, 4127-4128. http://dx.doi.org/10.1016/S0040-4039(01)90199-6

[19] Taafrout, M., Landais, Y., Robin, J.P. and Davoust, D. (1986) Isolation, Stereochemical Study, and Biomimetic Synthesis of Steganolide A, a New Dibenzocyclooctadieno-Lactone Lignan of Steganotaenia araliacea. Tetrahedron Let- 
ters, 27, 1781-1784. http://dx.doi.org/10.1016/S0040-4039(00)84373-7

[20] Ojerinde, S.O., Adepoju, B.A., Edache, J.J., Okundaye, E.M. and Alemika, T.E. (2001) Antioxidant and Antibacterial Constituents of Steganotaenia araliacea Stem Bark. Journal of Pharmacy \& Bioresources, 10, 25-32.

[21] Lino, A. and Deogracious, O. (2006) The in Vitro Antibacterial Activity of Annona senegalensis, Securidacca longipendiculata and Steganotaenia araliacea. African Journal of Health Sciences, 6, 31-35.

[22] Agunu, A., Abdurahman, E.M., Andrew, G.O. and Muhammed, Z. (2005) Diuretic Activity of the Stem-Bark Extracts of Steganotaenia araliacea Hochst [Apiaceae]. Journal of Ethnopharmacology, 96, 471-475. http://dx.doi.org/10.1016/j.jep.2004.09.045

[23] Wang, R.W., Rebhum, L.I. and Kupchan, S.M. (1977) Antimitotic and Antitubulin Activity of the Tumor Inhibitor Steganacin. Cancer Research, 37, 3071-3079.

[24] NjanNloga, A.M., Ngo Yebga, J. and Ngo Bum, E. (2014) Antiplasmodial Effect of Commelina benghalensis/Steganotaenia araliacea Plants Extract on the Human Population in Ngaoundere (Cameroon). Journal of Medical Sciences, 14, 68-74. http://dx.doi.org/10.3923/jms.2014.68.74

[25] Abubakar, M.S., Abdurahman, E.M., Nock, I.H., Haruna, A.K. and Garba, M. (2001) The Evaluation of Pest Control Properties of Steganotaenia araliacea. Journal of Herbs, Spices and Medicinal Plants, 8, 51-57. http://dx.doi.org/10.1300/J044v08n01_07

[26] Ndjonka, D., Agyare, C., Luersen, K., Hensel, A. and Liebau, E. (2010) In Vitro Anti-Leishmanial Activity of Traditional Medicinal Plants from Cameroon and Ghana. International Journal of Pharmacology, 6, 863-871. http://dx.doi.org/10.3923/ijp.2010.863.871

[27] Trease, G.E. and Evans, W.C. (1989) Pharmacognosy. 11th Edition, Bailliere Tindall, London, 45-50.

[28] Harbone, J.B. (1998) Methods of Extraction and Isolation. In: Phytochemical Methods, Chapman and Hall, London, 60-66.

[29] Noudjou, F., Ngassoum, M.B., Mapongmetsem, P.M., Marlier, M., Verscheure, M. and Lognay, G.C. (2006) Analysis by GC/FID and GC/MS of Essential Oil of Leaflets of Steganotaenia araliacea Hochst from Cameroon. Journal of Essential Oil Research, 18, 305-307. http://dx.doi.org/10.1080/10412905.2006.9699097

[30] Bakkali, F., Averbeck, A., Averbeck, D. and Idaomer, M. (2008) Biological Effects of Essential Oils-A Review. Food and Chemical Toxicology, 46, 446-475. http://dx.doi.org/10.1016/j.fct.2007.09.106

[31] Ciganda, C. and Laborde, A. (2003) Herbal Infusions Used for Induced Abortion. Clinical Toxicology, 41, 235-239. http://dx.doi.org/10.1081/CLT-120021104

[32] Fang, Y., Li, Z. and Watanabe, Y. (2003) Pharmacokinetics of a Novel Anti-Asthmatic Scoparone, in the Rabbit Serum Assessed by a Simple HPLC Method. Journal of Ethnopharmacology, 86, 127-130. http://dx.doi.org/10.1016/S0378-8741(03)00039-4

[33] Purup, S., Larsen, E. and Christensen, L.P. (2009) Differential Effects of Falcarinol and Related Aliphatic C 17 -Polyacetylenes on Intestinal Cell Proliferation. Journal of Agricultural and Food Chemistry, 57, 8290-8296. http://dx.doi.org/10.1021/jf901503a

[34] Kobaek-Larsen, M., Christensen, L.P., Vach, W., Ritskes-Hoitinga, J. and Brandt, K. (2005) Inhibitory Effects of Feeding with Carrots or (-)-Falcarinol on Development of Azoxymethane-Induced Preneoplastic Lesions in the Rat Colon. Journal of Agricultural and Food Chemistry, 53, 1823-1827. http://dx.doi.org/10.1021/jf048519s

[35] Ray, A. (2005) Review Article: Cancer Preventive Role of Selected Dietary Factors. Indian Journal of Cancer, 42, 1524. http://dx.doi.org/10.4103/0019-509X.15095 
Scientific Research Publishing (SCIRP) is one of the largest Open Access journal publishers. It is currently publishing more than 200 open access, online, peer-reviewed journals covering a wide range of academic disciplines. SCIRP serves the worldwide academic communities and contributes to the progress and application of science with its publication.

Other selected journals from SCIRP are listed as below. Submit your manuscript to us via either submit@scirp.org or Online Submission Portal.
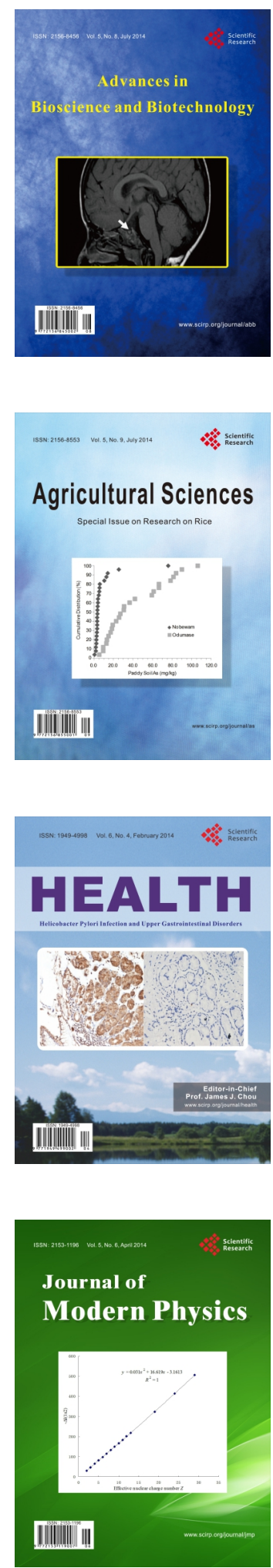
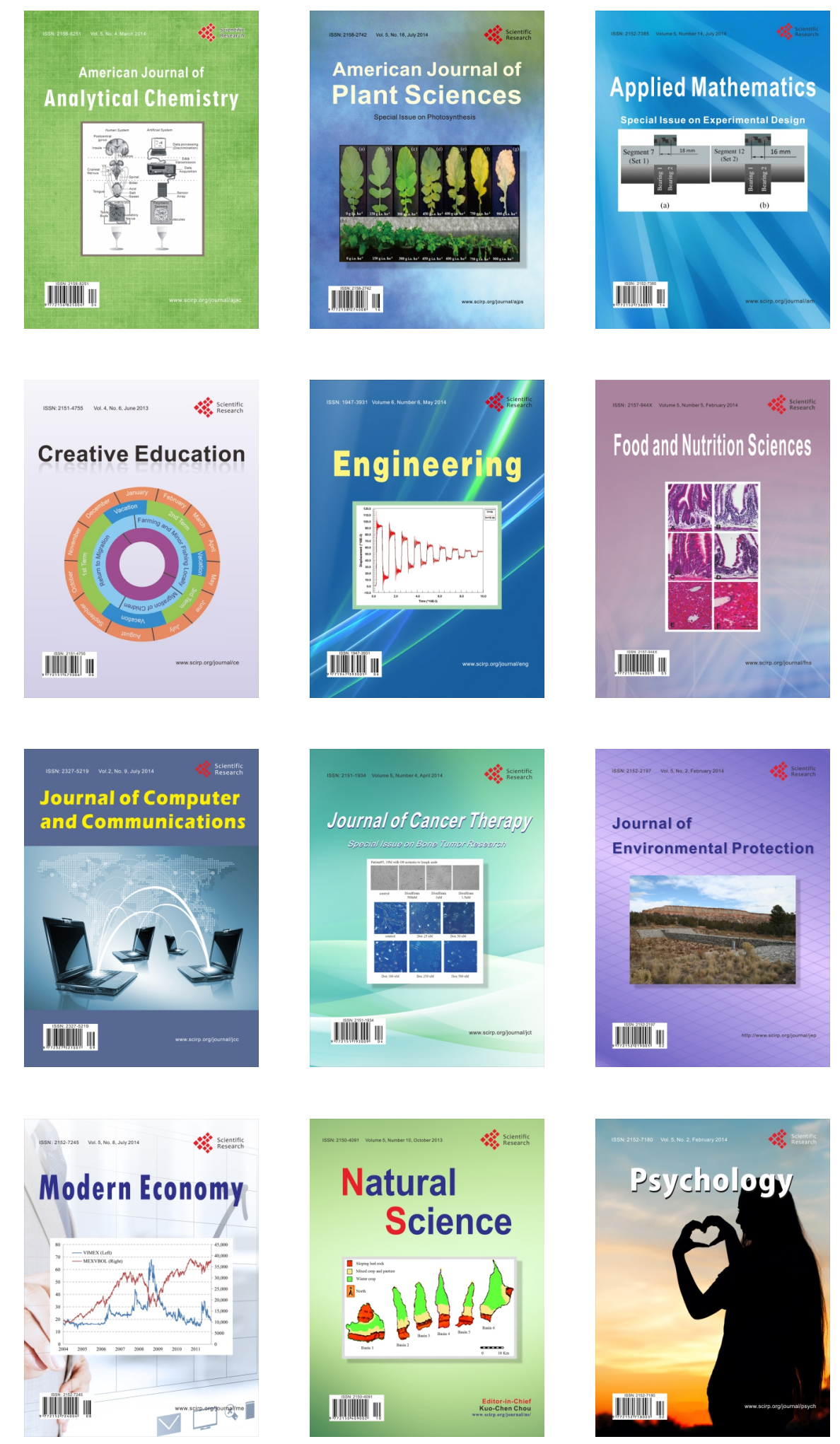